\title{
Evaluation of Tigris River by Water Quality Index Analysis Using $\mathrm{C}++$ Program
}

\author{
Allaa M. Aenab ${ }^{1}$, S. K. Singh ${ }^{1}$, Adil Abbas Majeed Al-Rubaye ${ }^{2}$ \\ ${ }^{1}$ Environmental Engineering Department, Delhi Technological University (DTU), Delhi, India \\ ${ }^{2}$ Electrical \& Communication Engineering Department, Al-Mansour University College, Baghdad, Iraq \\ Email: allaaaenab@gmail.com
}

Received April 3, 2012; revised May 1, 2012; accepted June 3, 2012

\begin{abstract}
In the capital city of Baghdad, The surface water suffering from effect of conservative pollutants. Baghdad city has two rivers, the main river Tigris River and Diyala River in boundary of Baghdad city (Jassir Diyala) eastern of Baghdad as is shown in Figure 1. The present study deals with the evaluation of water quality of Tigris River within Baghdad. In the case of Tigris River the concentrations of TH, TDS, $\mathrm{PO}_{4}$ and $\mathrm{SO}_{4}$ were found to lie outside the acceptable range of WHO standards by using WQI analysis and $\mathrm{C}++$ program.
\end{abstract}

Keywords: Tigris River; Water Quality; WQI; C++ Program and River Evaluation

\section{Introduction}

The main rivers of Iraq, the Tigris and the Euphrates which cover an area of $126,900 \mathrm{~km}^{2}$ and $177,600 \mathrm{~km}^{2}$ respectively, cross Iraq by their middle and lower reaches, eventually to confluence in the river Shatt Al-Arab, before flowing into the Arabian Gulf. The Tigris provides all the main tributaries within Iraq (Greater Zab, Lesser Zab, Adhaim and Diyala) with no tributaries sourced from the Euphrates. The arid regions along the watershed are characterized by the existence of "wadis" in the upper reached of Iraq. More than $90 \%$ of Iraq's water dependent needs are met by surface water and $80 \%$ of this water flow comes from its three neighboring countries [1].

The Tigris is $1850 \mathrm{~km}$ long, rising in the Taurus Mountains of eastern Turkey about $25 \mathrm{~km}$ southeast of the city of Elazig and about $30 \mathrm{~km}$ from the headwaters of the Euphrates. The river then flows for $400 \mathrm{~km}$ through Turkish territory before becoming the border between Syria and Iraq. This stretch of $44 \mathrm{~km}$ is the only part of the river that is located in Syria. The remaining $1418 \mathrm{~km}$ are entirely within the Iraqi borders [2]. Since 1965, when Horton (1965) proposed the first water quality index (WQI), a great deal of consideration has been given to the development of "water quality index" methods with the intent of providing a tool for simplifying the reporting of water quality data. However, there is no reliable water quality index has been developed in Iraq to assess water suitability of irrigation [3]. WQI is a set of standards used to measure changes in water quality in a particular river reach over time and make comparisons from different reaches of a river. A WQI also allows for comparisons to be made between different rivers. This index allows for a general analysis of water quality on many levels that affect a stream's ability to host life [4]. WQI is an arithmetical tool used to transform large quantities of water quality data into a single cumulatively derived number. It represents a certain level of water quality while eliminating the subjective assessments of such quality [5-7]. It is intended as a simple, readily understandable tool for managers and decision makers to convey information on the quality and potential uses of a given water body, based on various criteria [6]. Further more it turns complex water quality data into information that is understandable and usable by the public. It gives the public a general idea of the water quality in a particular region. Water Quality Index (WQI) is a very useful and efficient method for assessing the suitability of water quality. It is also a very useful tool for communicating the information on overall quality of water to the concerned citizens and policy makers. It, thus, becomes an important parameter for the assessment and management of water quality (both surface and groundwater). WQI reflects the composite influence of different water quality parameters and is calculated from the point of view of the suitability of (both surface and groundwater) for human consumption [8]. Table 1 showing Water Quality Index Ranges is $[9,10]$.

\section{Objectives and Approach}

The objectives are important tools, used in a framework 
Table 1. Water quality index categories.

\begin{tabular}{cccccc}
\hline WQI & $0-25$ & $26-50$ & $51-75$ & $76-100$ & $>100$ \\
\hline $\begin{array}{c}\text { Water } \\
\text { Quality }\end{array}$ & Excellent & Good & Poor & Very Poor & Unsuitable \\
\hline
\end{tabular}

Source: Brown et al., 1970 [10].

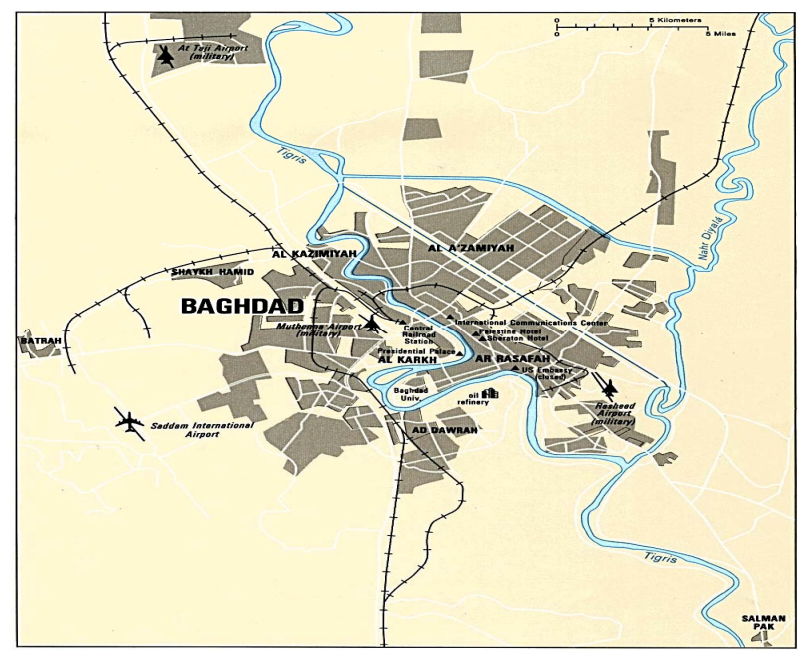

Figure 1. Map of Tigris River within Baghdad city.

of provincial and federal environmental assessment, risk management, and the application of best available treatment technology, which support the management, protection and enhancement of the surface water resources of the province [11]. The main objective of this paper is to develop an index method for assessing water quality to use this method to assess the general water suitability of irrigation for use in agriculture. Monitoring water quality parameters in Tigris River and calculate overall water quality index (WQI) for evaluate Tigris River water in study area by using $\mathrm{C}++$ program for this calculation.

\section{Materials and Methods}

\subsection{Study Area}

Both Tigris and the Euphrates are international rivers originating from Turkey. The Tigris river basin in Iraq has a total area of $253,000 \mathrm{~km}^{2}$, or $54 \%$ of the total river basin area. For the Tigris, average annual runoff as it enters Iraq is estimated at $21.2 \mathrm{~km}^{3}$. All the Tigris tributaries are on its left bank. From upstream to downstream [12]:

- The Greater Zab, which originates in Turkey and is partly regulated by the Bakhma dam. It generates $13.18 \mathrm{~km}^{3}$ at its confluence with the Tigris; $62 \%$ of the $25,810 \mathrm{~km}^{2}$ of river basin is in Iraq;

- The Lesser Zab, which originates in Iran and is equipped with the Dokan dam $(6.8 \mathrm{~km})$. The river ba$\sin$ of $21,475 \mathrm{~km}^{2}$ (of which $74 \%$ is in Iraqi territory) generates about $7.17 \mathrm{~km}$, of which $5.07 \mathrm{~km}^{3}$ of annual safe yield after the Dokan construction;

- The Al-Adhaim (or Nahr Al Uzaym) which drains about $13,000 \mathrm{~km}^{2}$ entirely in Iraq. It generates about $0.79 \mathrm{~km}^{3}$ at its confluence with the Tigris. It is an intermittent stream subject to flash floods;

- The Diyala, which originates in Iran and drains about $31,896 \mathrm{~km}^{2}$ of which $75 \%$ in Iraqi territory. It is equipped with the Darbandikhan dam and generates about $5.74 \mathrm{~km}^{3}$ at its confluence with the Tigris;

- The Nahr at Tib, Dewarege (Doveyrich) and Shehabi Rivers, draining together more than $8000 \mathrm{~km}^{2}$. They originate in Iran, and bring together in the Tigris about $1 \mathrm{~km}^{3}$ of highly saline waters;

- The Al-Karkha, whose course is mainly in Iran and, from a drainage area of $46,000 \mathrm{~km}^{2}$, brings about 6.3 $\mathrm{km}^{3}$ yearly into Iraq, namely into the Hawr Al Hawiza during the flood season, and into the Tigris River during the dry season.

Turkey shares the waters of the Tigris River with the states of Syria and Iraq. Particularly Iraq relies on the water of the Tigris River and could almost not have any agriculture and water supply of urban centers without the water of Tigris and Euphrates. The fact that the storage capacity of the proposed Ilisu Dam and other dam projects is larger (at least 21 Cubic Kilometers) than the annual water flow of the Tigris (17 Cubic Kilometers) from Turkey to Iraq, explains the high impact of this project [13]. The Tigris collects $43 \%$ of its flow in Turkey and $57 \%$ of its flow within Iraq from left-bank tributaries including the Greater Zab, Lesser Zab, Adhaim and Diyala Rivers. Usage of Tigris water within Iraq includes agricultural irrigation, and municipal water supply; the Tigris also has several water storage facilities for flood control and power generation within Iraq. Between 1928 and 1946, the average stream flow of the Tigris as it entered Iraq was $18 \mathrm{bcm} / \mathrm{yr}$; stream flow in the Tigris increased to $42 \mathrm{bcm} / \mathrm{yr}$ (billion cubic meters per year) past its confluence with the Diyala River; discharges south of this point reduced flow in the Tigris to $37 \mathrm{bcm} / \mathrm{yr}$ at Kut. Past Kut, the Tigris supplies water for irrigation and public water supply and also discharges to the Central Marsh. Combined, these discharges reduced its flow to $7 \mathrm{bcm} / \mathrm{yr}$ at Amarahh and $3 \mathrm{bcm} / \mathrm{yr}$ at Qalat Salih during this same time period [14].

\subsection{Samples Collection}

Water samples were collected from selected eight stations in Tigris River from January 2004 to December 2010. The samples were collected from just under water surface for analysis of selected parameters included: $\mathrm{pH}$, biological oxygen demand $\left(\mathrm{BOD}_{5}\right)$, nitrate $\left(\mathrm{NO}_{3}\right)$, phosphate $\left(\mathrm{PO}_{4}\right)$, Total Dissolved Solids (TDS), Total Hardness (TH), Magnesium (Mg), Calcium (Ca), Chlorides $(\mathrm{Cl})$, Sulphates $\left(\mathrm{SO}_{4}\right)$, Sodium $(\mathrm{Na})$ and electrical con- 
ductivity (EC).

\subsection{Application of C++ Program}

\subsubsection{Introduction}

$\mathrm{C}++$ is a statically typed, free-form, multi-paradigm, compiled, general-purpose programming language. $\mathrm{C}++$ is sometimes called a hybrid language. It is regarded as an intermediate-level language, as it comprises a combination of both high-level and low-level language features [15]. It was developed by Bjarne Stroustrup starting in 1979 at Bell Labs as an enhancement to the C language. Originally named $\mathrm{C}$ with Classes, the language was renamed $\mathrm{C}++$ in 1983 [16]. $\mathrm{C}++$ is one of the most popular programming languages $[17,18]$ with application domains including systems software, application software, device drivers, embedded software, high-performance server and client applications, and entertainment software such as video games [19]. Several groups provide both free and proprietary $\mathrm{C}++$ compiler software. $\mathrm{C}++$ has greatly influenced many other popular programming languages, most notably C\# and Java. After years of development, the $\mathrm{C}++$ programming language standard was ratified in 1998 as ISO/IEC 14882:1998. The standard was amended by the 2003 technical corrigendum, ISO/ IEC 14882:2003. The current standard extending C++ with new features was ratified and published by ISO in September 2011 as ISO/IEC 14882:2011 (informally known as $\mathrm{C}++11$ ) [20,21].

\subsubsection{Algorithms and Steps}

In my work using language $\mathrm{C}++$ under window to execution, and perform some steps to implementation this program:

- Create Project File consist of number of files.

- Create dialog boxes that perform to dialog with users.

- Read and input Data to system for all stations from users.

- Select type of process from menu (Normality Test, Z-Test, t_Test, ANOVA (analysis of variance) Test and Water Quality Index).

- Execution algorithm and calculate mathematics for all process after enter data.

- Display Result with high speed (Less than 1 second). As is shown in Figure 2.

\subsubsection{Water Quality Index Calculation}

The WQI was calculated using the standards of drinking water quality recommended by the World Health Organization (WHO). The weighted arithmetic index method [10] was used for the calculation of WQI of the surface water. Further, quality rating or sub index (qn) was calculated using the following expression.

$$
\mathrm{qn}=100[\mathrm{Vn}-\mathrm{Vio}] /[\mathrm{Sn}-\mathrm{Vn}]
$$

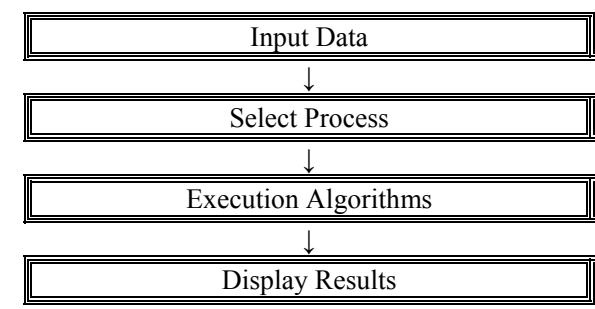

Figure 2. C++ diagram.

(Let there be $\mathrm{n}$ water quality parameters and quality rating or sub index (qn) corresponding to nth parameter is a number reflecting the relative value of this parameter in the polluted water with respect to its standard, maximum permissible value).

$\mathrm{qn}=$ Quality rating for the $\mathrm{nth}$ water quality parameter.

$\mathrm{Vn}=$ Estimated value of the nth parameter at a given sampling point.

$\mathrm{Sn}=$ Standard permissible value of the nth parameter.

$\mathrm{Vio}=$ Ideal value of nth parameter in pure water (i.e. 0 for all other parameters except the parameter $\mathrm{pH}$ and Dissolve Oxygen (7.0 and $14.6 \mathrm{mg} / \mathrm{L}$ respectively).

Unit weight was calculated by a value inversely proportional to the recommended standard.

value $\mathrm{Sn}$ of the corresponding parameter.

$\mathrm{Wn}=\mathrm{K} / \mathrm{Sn}$.

Wn unit weight for the nth parameters.

$\mathrm{Sn}=$ standard value for the nth parameters.

$\mathrm{K}=$ constant for proportionality.

The overall WQI was calculated by aggregating the quality rating with the unit weight linearly.

$$
\mathrm{WQI}=\sum \mathrm{qnWn} / \sum \mathrm{Wn} \text {. }
$$

\section{Results}

Table 2 presents the result of the physical parameters of surface water quality. The result showed that Total Hardness $(\mathrm{TH})$ in very high range and cross WHO limit $(344.4 \mathrm{mg} / \mathrm{l})$ and phosphate $\left(\mathrm{PO}_{4}\right)$ in highest value and cross WHO standard $(0.3 \mathrm{mg} / \mathrm{l})$. Also we found the electrical conductivity (EC) in high value $(1175.7 \mathrm{mg} / \mathrm{l})$ and that more than WHO standard. WQI for the year of 2004 it was $589.1552>100$ this means unsuitable for use.

Figure 3 shows all the years (2004, 2005, 2006, 2007, $2008,2009 \& 2010)$ the result almost same all results of WQI was above 100 and that makes surface water in Tigris River unsuitable for use.

\section{Conclusions}

The year of 2004 has three parameters out of WHO standard values, it was TH $(344.4 \mathrm{mg} / \mathrm{l}), \mathrm{PO}_{4}(0.3 \mathrm{mg} / \mathrm{l})$ and EC (1170.1 mg/l), WQI in total was (589.1552). For the year of 2005, $2008 \& 2009$ it has five parameters out of WHO standard values and that parameters is $\mathrm{TH}$ 
Table 2. Water Quality Index result by $\mathrm{C}++$ program for the year 2004.

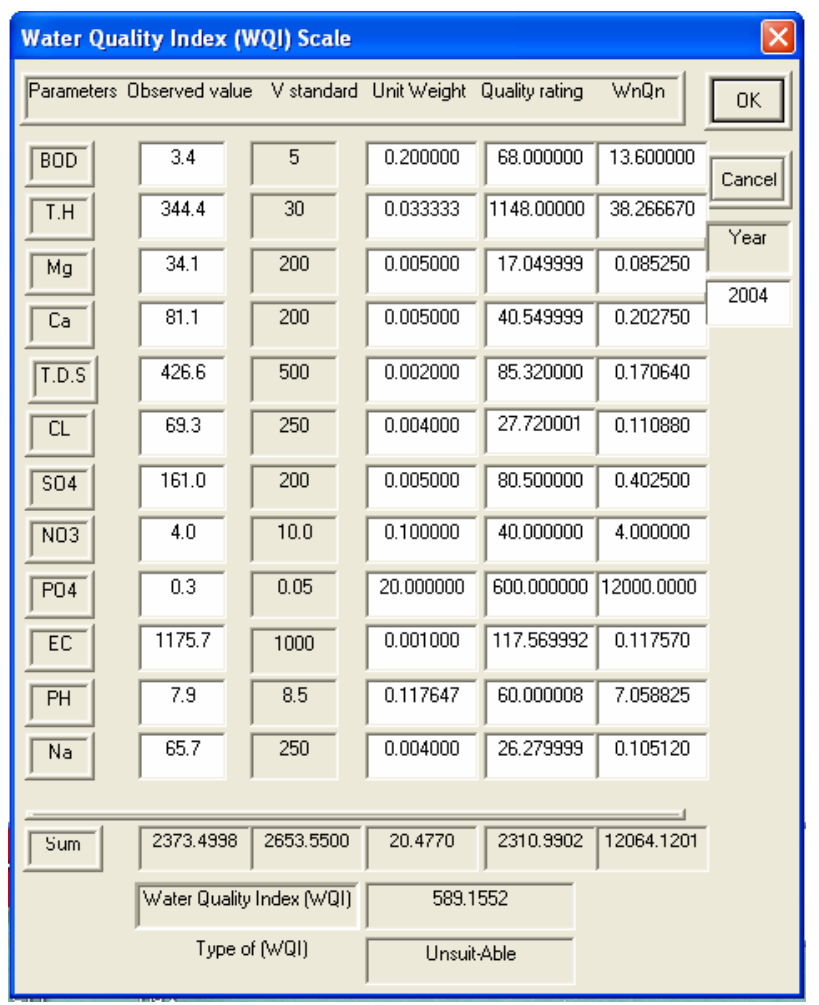

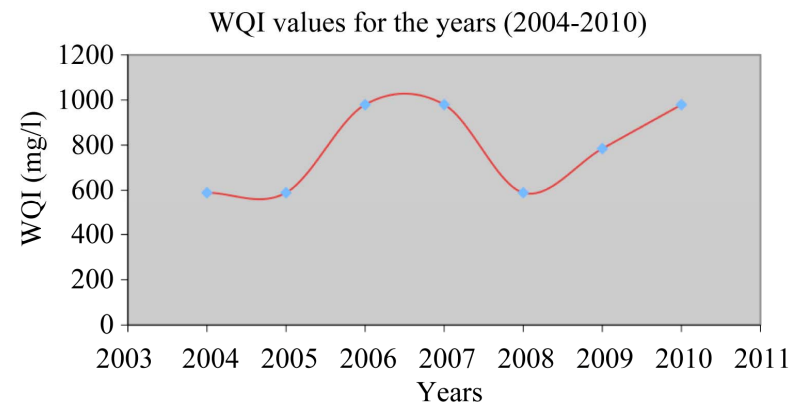

Figure 3. Water Quality Index (WQI) values for the years (2004-2010).

(389.975, $421.225 \& 416.575 \mathrm{mg} / \mathrm{l})$, respectively, T.D.S $(611.89,616.1373 \& 626.74 \mathrm{mg} / 1), \mathrm{SO}_{4}(237.5,201 \&$ $201.1 \mathrm{mg} / \mathrm{l}), \mathrm{PO}_{4}(0.325,0.325 \& 0.375 \mathrm{mg} / \mathrm{l})$ and $\mathrm{EC}$ $(1170.1,1175.78 \& 1170.1 \mathrm{mg} / \mathrm{l})$, WQI in total was (638.1017, 638.0811\& $\& 35.7739)$. In $2006 \& 2007$ there is four parameters out of WHO standard values, it was TH (337.2 \& $321.55 \mathrm{mg} / \mathrm{l})$, respectively, T.D.S (618.1 \& $583.525 \mathrm{mg} / \mathrm{l}), \mathrm{SO}_{4}(245.975 \& 244.775 \mathrm{mg} / \mathrm{l})$ and $\mathrm{PO}_{4}$ $(0.45 \& 0.525 \mathrm{mg} / \mathrm{l})$, WQI in total was $(881.8434 \&$ $1028.4301)$. Finally in year of 2010 has two parameters out of WHO standard limit values, the parameters was TH $(285.6 \mathrm{mg} / \mathrm{l})$ and $\mathrm{PO}_{4}(0.463 \mathrm{mg} / \mathrm{l})$, WQI in total (907.1375).

From all above result we can see all of WQI > 100 and that's means WQI type is unsuitable for use.

\section{REFERENCES}

[1] Geopolicity, "Managing the Tigris-Euphrates Watershed: The Challenge Facing Iraq," 2010, pp. 3-10. http://zunia.org/uploads/media/knowledge/Geopolicity $\% 2$ 0-\%20Managing\%20the \%20Tigris\%20and\%20Euphrates $\%$ 20Watershed $\% 20-\% 20$ The $\% 20$ Challenge $\% 20$ Facing $\%$ 20Iraq1280855782.pdf

[2] V. A. Isaev, et al., "The Hydrology, Evolution, and Hydrological Regime of the Mouth Area of the Shatt Al-Arab River," Water Resources, Vol. 36, No. 4, 2009, pp. 380-395. doi:10.1134/S0097807809040022

[3] A. J. K. Al Meini, “A Proposed Index of Water Quality Assessment for Irrigation," Engineering \& Technology Journal, Vol. 28, No. 22, 2010, pp. 6557-6561.

[4] K. Ashwani, et al., "Water Quality Index for Assessment of Water Quality of River Ravi at Madhopur (India)," Global Journal of Environmental Sciences, Vol. 8, No. 1, 2009, pp. 49-57.

[5] N. Štambuk-Giljanović, "Water Quality Evaluation by Index in Dalmatia," Water Research, Vol. 33, No. 16, 1999 , pp. 3423-3440. doi:10.1016/S0043-1354(99)00063-9

[6] N. Štambuk-Giljanović, "Comparison of Dalmatian Water Evaluation Indices," Water Environment Research, Vol. 75, No. 5, 2003, pp. 388-405. doi:10.2175/106143003X141196

[7] W. W. Miller, et al., "Identification of Water Quality Differences in Nevada through Index Application," Journal of Environmental Quality, Vol. 15, No. 3, 1986, pp. 265-272. doi: $10.2134 /$ jeq $1986.00472425001500030012 \mathrm{x}$

[8] Akoteyon, et al., "Determination of Water Quality Index and Suitability of Urban River for Municipal Water Supply in Lagos-Nigeria," European Journal of Scientific Research, Vol. 54, No. 2, 2011, pp. 263-271. http://www.eurojournals.com/ejsr.htm

[9] A. Hameed, et al., "Evaluating Raw and Treated Water Quality of Tigris River within Baghdad by Index Analysis," Journal of Water Resource and Protection, Vol. 2, 2010, pp. 629-635. doi:10.4236/jwarp.2010.27072

[10] R. M. Brown, N. I. McClelland, R. A. Deininger and R. G. Tozer, "A Water Quality Index-Do We Dare?" Proceedings of the National Symposium on Data and Instrumentation for Water Quality Management, Conference of State Sanitary Engineers and Wisconsin University, Madison, 21-23 July 1970, pp. 364-383.

[11] EPB 356, "The Surface Water Quality Objectives. Drinking Water Quality Section. Saskatchewan Environment," July 2006, pp. 1-15.

http://www.se.gov.sk.ca/environment/protection/water/su rface.asp

[12] S. Grego, et al., "Water Purification in the Middle East Crisis: A Survey on WTP and CU in Basrah (Iraq) Area within a Research and Development Program," Desalination, Vol. 165, 2004, pp. 73-79.

[13] UNESCO, "Background Information on the Petition to 
Save Potential World Heritage on the Tigris River in Mesopotamia Directed to the World Heritage Committee of the UNESCO," 14 March 2012, pp. 1-3.

http://www.gegenstroemung.org/drupal/sites/default/files/ Ilisu_UNESCO_Petition_2012_Background.pdf

[14] The Iraq Foundation, "Draft Report Physical Characteristics of Mesopotamian Marshlands of Southern Iraq," 2003, pp. 21-25.

http://www.iraqfoundation.org/edenagain/publications/pd fs/physicalcharreport.pdf

[15] H. Schildt, "C++ The Complete Reference Third Edition," Osborne McGraw-Hill, 1998, pp. 23-28.

[16] B. Stroustrup, "C++ Faq: When Was C++ Invented," 7 March 2010, Retrieved 16 September 2010, pp. 11-19. http://www2.research.att.com/ bs/bs_faq.html\#invention

[17] "Programming Language Popularity," 2009, Retrieved 16
January 2009, pp. 2-9. http://www.langpop.com/

[18] “TIOBE Programming Community Index," 2009, Retrieved 3 August 2011, pp. 1-2.

http://www.tiobe.com/index.php/content/paperinfo/tpci/in dex.html

[19] C++ Applications, "What's CvSDL?" Retrieved 8 March 2010, pp. 2-3.

http://www.cvsdl.com/:c c sdl. http://www.cvsdl.com/

[20] ISO, “ISO/IEC 14882:2011,” Retrieved 3 September 2011. http://www.iso.org/iso/iso_catalogue/catalogue_ics/catalo gue detail ics.htm?ics $1=35 \& i c s 2=60 \& i c s 3=\&$ csnumber $=50372$

[21] "Most Popular Programming Languages," Retrieved 7 September 2011, pp. 2-4. http://langpop.com/ 